\title{
Bir Kent Belleği Unsuru Olarak Yüzey Seramikleri ve Sao Bento Tren İstasyonu Örneği
}

\author{
Surface Ceramics as An Element of Urban Memory and The Example of Sao \\ Bento Train Station in Porto
}

Deniz Onur Erman

Doç., Ankara Hacı Bayram Veli Üniversitesi Güzel Sanatlar Fakültesi Resim Bölümü, denizonur2005@gmail.com

\section{$\ddot{O} \mathbf{z}$}

İnsanoğlu tarih boyunca kültürel birikiminin bir göstergesi olarak mimari ve sanatsal yapılar oluşturmuş, kültürel varlığını sonraki nesillere aktarmanın türlü yollarını bulmuştur. İnsan için kimi zaman bu mekânlar geçmiş yaşantıları ile bağ kurmalarını sağlayan, geçmiş-gelecek entegrasyonu açısından önemli kültürel semboller olabilmektedir. Hergün önünden geçilen bir postane binası, görkemli bir anıt, önünde buluşulan heykel, çocukluğumuza ve kendi çocuklarımızın çocukluğuna da şahit olan eski tiyatro binası, ayrılıkların ve kavuşmaların şahidi tarihi tren garı insanın köklerini, yaşadığı kentin derinlerine salmasına yardımcı olur. Sadece kendi geçmişine değil, yaşadığı tarihe, coğrafyaya saygıyla bağlanmasına ve bu değerleri gelecek nesillere de aktarmak için çaba duymasını sağlar. Kent belleği, kent sakinlerinin kültürel, sosyal, tarihsel deneyimleriyle birlikte inşa ettikleri bir kollektif bellektir. Kentleri zenginleştiren tarihi yapılar o toplumların kültürel ve sanatsal birikimlerinden doğmakta ve bu kültürel donanım sonraki nesillere aktarılarak kültürel belleğin oluşumunu sağlamaktadır.

Seramik çağlar boyunca uygarlı̆̆ın gelişimine 1şık tutmuş, yer aldığı toplumun ekonomik, siyasal ve kültürel gelişiminin bir göstergesi olmuştur. Tarih boyunca insanların seramiği mimari bir eleman olarak türlü şekillerde kullandıkları bilinmektedir. Mimari bir unsur olarak iç ve dış mekânlarda yüzeyde kullanımı en sık karşılaşılan türüdür. Tarih boyunca alçak-yüksek rölyefler biçiminde, mozaik şeklinde, klasik veya modern panolar halinde, resimsel ögelerin yansıtılması şeklinde sırlı ve sırsız türlü biçimlerde uygulama alanı bulmuştur. Dünyadan pek çok özgün örnekler ile desteklenecek olan bu konuda bir kent belleği unsuru olarak Porto Sao Bento merkez tren istasyonu firça dekorlu sırlı seramik yüzey kaplamalarıyla ayrıcalıklı bir yere sahip olup, üzerinde durulması gereken, araştırılmaya değer önemli bir örnektir.

Anahtar kelimeler: Kent belleği, kent kimliği, yüzey seramiği, seramik karo, azulejo, Sao Bento tren istasyonu, Porto

\begin{abstract}
Throughout history, humankind has devised various ways of conveying his cultural heritage to oncoming generations, most commonly in the form of artistic and architectural creations as examples of his cultural existence. For the residents of the city, these locations and buildings may in time become important cultural symbols, enabling them to connect with their past lives and to integrate the past and the future. The post office that one goes by every day, a glorious monument, the statue before which people have rendezvous, the old theatre building that has witnessed our childhood as well as
\end{abstract}


that of our children, the train station where uncountable separations and reunions take place, all help inhabitants to form strong roots that go deep in the city. These do not only assist in connecting with one's past, but also in establishing a respectful attachment with the history and geography that he or she lives in and eventually lead to will and efforts to pass these values to future generations. City memory is a collective memory that is made of the social, cultural and historical experiences of the residents. Historical buildings that enrich cities are actually the products of the cultural and artistic background of the society and this cultural heritage is passed on to form a collective memory that spans multiple generations.

Ceramics has always shed light on the development of civilization and has been an indicator of the economic, political and cultural progress of the society. Throughout history, people have used ceramics as architectural elements, among innumerable other uses. The most common practice is to use ceramics on inner and outer surfaces of buildings. High and low reliefs, mosaics, classical or modern panels with or without glaze have been widely used to depict decorative or illustrative forms. Porto Sao Bento Central Train Station is a unique and magnificent example of a such structures. This is a huge building, covered on the inside by massive brush-décor glazed ceramics and certainly merits mention and study. Other prominent examples of buildings with surface ceramics which have important roles in their corresponding urban memories will also be presented.

Keywords: Urban memory, city identity, surface ceramics, ceramic tile, azulejo, Sao Bento Train Station, Porto

\section{Giriş}

İnsan, biyolojik ve kültürel evrimini tamamlarken ilk önce beslenme ve temiz su temini gibi en temel yaşamsal ihtiyaçlarını karşılamaya odaklanmıştır. İkincil olarak da dış faktörlerden kaynaklı tehlikelerden korunmaya ve güvenlik ihtiyaçlarını karşılamaya yoğunlaşmıştır. Binlerce yıldır değişim ve dönüşüm geçiren yerleşme kavramı zamanla kent kavramı ile özdeş hale gelmiştir. Bu kavram, insanın yerleşik hayata geçmeye başlamasından günümüze kadar uzanan geniş bir süreci kapsar ve insanın sadece barınmasını sağlayan korunaklı bir mekân olmanın çok ötesinde anlamlar içermektedir. "Kent kavramı, sadece yaşantının sürdürüldüğü fiziki bir mekân olmanın ötesinde sosyal, kültürel, ekonomik, jeopolitik vb. etkenlere göre şekillenen, zamanla kendine özgü bir kimliğe kavuşan, aynı zamanda yaşayanların kente dair bilgi, duygu ve yaşanmışlıklarını da kapsayan organik bir yapı olarak değerlendirilmelidir" (Arı ğ, 2018, s. 16). İnsan çevresiyle birlikte birbirinden ayrılmaz bir bütün olarak birbirinden etkilenen ve birbirini etkileyen aynı zamanda dönüştüren bir yapı gibidir. Buradan yola çıkarak kentlerin, insanların barındıkları, ürettikleri, sosyalleşip, aidiyet duydukları, kültürel gereksinimlerini karşıladıkları, sürekli toplumsal gelişme içerisinde bulundukları mekânlardan oluştuklarını söylemek yanlış olmayacaktır. İnsan, yerleştiği bölgede önce güvenliğini sağlamış daha sonra medeniyetin bir getirisi olarak sonraki nesillere kalıcı izler bırakmıştır. Bunu yaparken de dönemsel değişiklikler gösteren sanatsal ve estetik kaygılar üretimlerini beslemiş ve kaynaklık etmiştir. İnsan güven duyduğu topraklara yerleşir, yaşantısından, inancından izler bırakarak burada kök salar. Aidiyet tarih boyunca insanın vazgeçilmez arayışlarınının başında gelmiştir. Etkilendiği ve etkilediği topraklarda kültürlenir insan ve burada ortaya koyduğu üretimlerinin sürekli olması onun için hayati önem arz eder. İnsanın, tabiatında taşıdığı soyunu bir sonraki nesile bırakma dürtüsü gibi yapıtlarını, kültürünü sonraki nesillere aktarma dürtüsü de yaşamsaldır ve beslenmelidir. 


\section{Yöntem}

$\mathrm{Bu}$ çalı̧̧mada betimsel ve karşılaştırmalı araştırma yöntemleri kullanılmıştır. Konuya ilişkin tarihsel süreç araştırılmış, literatür taraması yapılmış, konu etraflıca tanımlanmaya çalışılmıştır. Kent belleğinin toplumsal farklılıklarına yer verilen kısımlarda konu karşılaştırmalı olarak aktarılmaya çalışılmıştır.

Dünyadan pek çok özgün örnekler ile karşılaştırmalı olarak ortaya konulmaya çalışılan bu araştırmada bir kent belleği unsuru olarak Porto Sao Bento merkez tren istasyonu firça dekorlu sırlı seramik yüzey kaplamaları seçilmiş ve ayrıca Olay-Vaka (Anekdot) Kaydı yöntemi ile konu araştırılmak üzere bölgeye gidilerek bizzat gözlemlenmiş ve fotoğraf ve dökümanlar elde edilerek gözlemin objektif bir biçimde kaydedilmesi sağlanmıştır. Araştırmada yer alan bazı görseller yazara ait kişisel fotoğraf arşivinden kullanılmıştır. Porto ve Lizbon kentlerinde yer alan ve hala geleneksel el boyaması sırlı seramik duvar fayansları üretimi yapan atölyeler ziyaret edilmiş ve teknik bilgi sağlanarak teorik bilgi desteklenmiştir. Bölgede bulunan lokal kitapçılardan alınan istasyona ait müze katalogları, tarih kitapları ve yazılı pek çok kaynaklar ile literatür taraması zenginleştirilmiştir. Bu yönleri ile bu çalışmanın, üzerinde durulması gereken, araştırılmaya değer önemli bir konu olduğu ve kendinden sonra gelen araştırmalar için kaynak oluşturacağı düşünülmektedir.

\section{Kültür ve Kent Kültürü}

Kültür en temel tanımıyla, insanın maddi ve manevi olarak ürettiği, ortaya koyduğu herşey olarak tanımlanabilir. Biraz daha açmak gerekirse kültür;

Bir toplumun duyuş ve düşünüş birliğini oluşturan, gelenek durumundaki her türlü yaşayış, düşünce ve sanat varlıklarının topu. Tarihsel ve toplumsal gelişme süreci içinde yaratılan her türlü değerlerle bunları kullanmada, sonraki kuşaklara iletmede kullanılan, insanın doğal ve toplumsal çevresine egemenliğinin ölçüsünü gösteren araçların tümü olarak tanımlanmaktadır (Kültür, 2017).

Kentin geçmişi ve bugünü arasındaki bağı oluşturan değerler bütünü kent kültürünü oluşturmaktadır. Uludağ, 'kent kültürü' kavramını şöyle tanımlamaktadır; "Bir kentin doğal çevresi, 'yapay çevresi', 'fiziki mekânları ve insanları' ve 'tutum ve davranışları' üçlüsünün ilişkilerinden doğan, izlenim, düşünce ve değerlendirmelerinin toplamıdır. Başka bir ifadeyle, kenti oluşturan bütün öğelerinin toplamı üzerine getirilen düşünce ya da değerlendirme kent kültürüdür” (Uludağ, 2000, s. 4). Kent kültürü kenti oluşturan doğal ve yapay bütün ögelerin toplamı olan canlı bir olgudur. İnsanın kültürel zenginliğinin yansıdığı sanatsal üretimleri de kent kültürünün vazgeçilmez bir parçasını oluşturmaktadır.

Sanatın kültürel değerlerin oluşmasında olduğu kadar aktarılmasında da etkin bir rol aldığı, gerçekleştirildiği dönemin değer yargıları, toplumsal, sosyolojik yapı, bilimsel gelişmeler gibi birçok bilginin kuşaktan kuşağa aktarılmasına katkıda bulunduğu açıktır. Dolayısıyla, belirli bir tarihsel gelişime sahip olan kentlerin geçmişi ve bugünü arasındaki bağın sağlam bir şekilde kurulabilmesinin ancak kente ait verilerin kesintisiz ve eksiksiz bir biçimde korunması ile mümkün olabileceği anlaşılmaktadır (Arı̆̆, 2018, s. 18).

İnsanoğlu tarih boyunca kültürel birikiminin bir göstergesi olarak tarihi ve dini yapılar, meydan heykelleri, anıtlar, parklar, müzeler, kamu yapıları vb. oluşturarak kültürel varlığını sonraki nesillere aktarmanın türlü yollarını bulmuştur. Bu yapılar da kentin geçmişine dair okumaların yapılabilmesinde, bölge sakinlerinin geçmiş ve gelecek yaşantılarının sağlanmasında ve kültürel etkileşimlerinde en güçlü rolu oynamaktadır. Kentlerin fiziki ve kültürel gelişimi kimi olaylarla kesintiye uğrayabilir. Doğal felaketler, savaşlar, büyük kayıplı salgın hastalıklar, yangınlar, büyük ölçekli göçler, devrimler, rejim değişiklikleri, darbeler gibi toplumun tamamını etkileyen tarihsel gelişmeler kent ve kent yaşantısı 
üzerinde radikal değişikliklere neden olurlar. Bunların doğal sonuçları olarak kent ve yaşantısı üzerinde kalıcı veya geçici izler bırakabilir, içerisinde yaşayanları bu gelişmeler neticesinde yaşam alanlarını yeniden düzenlemekle karşı karşıya getirebilir.

Kentleri oluşturup kuranlar içinde yaşayan insanlar olduğuna göre ve insanın zaman içerisindeki değişimi onun tabiatının kaçınılmaz bir özelliği olduğuna göre bundan elbette mekânlar da etkilenecektir. Kentlerin, özellikle de son dönemlerde küreselleşen dünyada kendisine yer edinmek için farklı parametrelere bağlı olarak gelişme ve değişme çabasına girmiş oldukları dikkat çekmektedir. Yaşanan dönüşümler, etkisini öncelikle kentsel mekânlarda göstermektedir. Değiş̧im olumlu yönde olabileceği gibi tersine de olabilmektedir. Yaşanan değişimler kent kültürüyle ve kente özelliğini veren yapıların karakteriyle örtüşmediği durumlarda kentin özgünlüğünün korunmasını imkânsız hale getirebilmektedir. Eski kent dokusu ile yeni arasında uyumsuzluk yaşanır, kimlik sorunları doğar. Schulz'a göre; kentin hızlı değişimi, sadece kentin kimliğini yitirmesine neden olmaz aynı zamanda bu hızlı değişime ve yeni kent kimliğine uyum sağlayamayan insanların, kentlerine yabancılaşmasına neden olur (Schulz,1971'den aktaran Alpak, Düzenli ve Eren, 2018, s. 520). Kent-insan bağı zayıflar bu da beraberinde sahiplenme duygusunu azaltır. İnsan için kimi zaman mekânlar geçmiş yaşantıları ile bağ kurmasını sağlayan, geçmiş-gelecek entegrasyonu açısından önemli kültürel semboller olabilmektedir, bunun eksikliği insanın duygu durumunda olumsuzluklara neden olur.

"Kentin en önemli mekânsal değeri olan merkezle kurulan ilişkiler azaldıkça, sahiplenme, aidiyet gibi unsurlar azalmakta, kentin kültürel dokusundaki yerini kaybeden kentli, pasif bir konumda tüm bu değişimlerin seyircisi haline gelmektedir" (Kösten, 2015'den aktaran Alpak ve diğerleri, 2018, s. 520).

Kentsel kimlik eski ve yeninin birbirlerine uyum sağlayarak bir arada bulunması ile sürdürülebilir. Eskinin korunması sadece fiziksel olanın korunması değil, aynı zamanda, o yer üzerinden ilişki kuran tüm öznelerin aidiyeti, sahipliliği ve kent kimliğini oluşturan tüm zamansal birikimlerin de korunması anlamına gelmektedir (Alpak ve diğerleri, 2018, s. 521).

Hergün önünden geçilen bir postane binası, yıllarca hiç değişmeden aynı yerde görmeye alışık olunan görkemli bir anıt, önünde buluşulan aynı heykel, çocukluğumuza ve kendi çocuklarımızın çocukluğuna da şahit olan eski tiyatro binası, ayrılıkların ve kavuşmaların şahidi tarihi tren garı insanın köklerini, yaşadığı kentin derinlerine salmasına yardımcı olur. Sadece kendi geçmişine değil, yaşadığ 1 tarihe, yaşadığı coğrafyaya saygıyla bağlanmasına ve bu değerleri gelecek nesillere de aktarmak için çaba duymasını sağlar. Ercoşkun'a göre; sahiplenme, insanların mekânla etkileşimlerinden doğan bir eğilimi ve mekâna yönelik yaşadıkları duygusal bağı ifade ederken, yer kimliği ise, insanın mekânla olan deneyiminde ve mekâna yönelik bağl1lı̆̆ının gelişiminde, aidiyet sürecine işaret eder. Mekâna bağlılık ve aidiyet duygusu tek taraflı bireysel bir oluşum olmamakla beraber; kişiler, kimlikler ve mekânlar arasındaki karşılıklı etkileşim söz konusudur (Ercoşkun, Akünal, Yenigül ve Alkan, 2016, s. 20).

\section{Kent Belleği Kavramı}

Kent belleği, kent sakinlerinin kültürel, sosyal, tarihsel deneyimleriyle birlikte inşa ettikleri bir kollektif bellektir. Olgun (2009), kent belleği kavramını; "bir kentin hem fiziksel yapısının hem de içerdiği yaşam tarzlarının yarattığı değerler bütünü” olarak tanımlamaktadır (s. 141).

Bellek, tekil olarak bireyin anları saklama ortamı olsa da, bireyin toplumsallığının bir ürünü olarak ortaya çıkar dolayısıyla, belleğin gerçekleştirdiği hatırlama ve anımsama edimi, onun yalnızca kendi deneyimlediği ve varoluşu salt kendisine bağlı anılar üzerinden gerçekleşmez. Bu açıdan, bireylerin birbirleri ve çevre üzerindeki etkileri ve grup bilinci hafızanın da kolektif bir şekilde çalışmasını sağlar (Al, 2011, s. 23). 
Turgay'a (2009) göre, mekân fiziksel ve kavramsal olarak farklı anlamlar çağrıştırmaktadır. Mekân, anlamsal olarak fiziki bir ortam olmanın ötesinde soyut bir anlam taşımaktadır ve bu soyut anlam, onun kültürel bir öğe olarak değerlendirilmesini gerektirir (aktaran Al, 2011, s. 26).

Mekân, daha çok mimari disipline ait bir kavram olarak düşünülse de, sosyoloji, sanat tarihi, arkeoloji, psikoloji, ekoloji gibi farklı disiplinlerin çalışma alanlarına giren ve sanatın farklı dallarını da doğrudan ilgilendiren çok yönlü bir kavram olarak karşımıza çıkmaktadır. Mekân, tarihsel süreç içerisinde sanatsal gelişim ve değişimlerden de direkt etkilenmiştir. Mekân ve sanat, yolları her daim kesişen, yaratıcı ifade biçiminin iki farklı alanda ortaya çıkmış halleri gibidir. "Sanat tarihsel süreçte de her dönem ele alınan mekân, kentsel değerlerin oluşması, kent belleğinin korunması ve gelişmesi, içerisinde yaşayanların çevre ile sıkı bağlar kurabilmesini sağlayan katalizör görevini üstlenmektedir” (Arı̆̆, 2018, s. 19). Kentleri zenginleştiren tarihi yapılar o toplumların kültürel ve sanatsal birikimlerinden doğmakta ve bu kültürel donanım sonraki nesillere aktarılarak kültürel belleğin oluşumunu sağlamaktadır. Kentin varlığı ancak eski ve yeninin birbirlerine uyum sağlayarak bir arada bulunması ile sağlıklı bir şekilde sürdürülebilir. Eskinin korunması sadece fiziksel olarak bir korumaya işaret etmez. Aynı zamanda, o yer üzerinden ilişkide bulunan tüm öznelerin sahipliliği, âidiyeti, ve kent kimliğini oluşturan tüm zamansal birikimlerin de korunması anlamına gelmektedir.

Kentin fiziki olduğu kadar tarihi ve kültürel birikimini de günümüze taşıyan yapılar, toplumun manevi değerlerinin yaşaması, unutulmaması için dikilen anıtlar, meydanlar, açık alan heykelleri gibi birçok öğe hızlı değişim ve dönüşümler karşısında yaşadığı çevreye yabancılaşmaya başlayan insanı bir nebze de olsa bu duygusundan uzak tutmaya çalışmaktadır.

Tarih boyunca kimi toplumlar geçmişi ve bugünü arasındaki bağın kurulmasını sağlayan kültürel mirası gelecek kuşaklara aktarmada sanatın güçlü ve dinamik yapısından faydalanmayı başarabilmişlerdir. Sanatçılar içerisinde yaşadığı toplumun gelenek, görenek, dil, inanç sistemleri ve dünya görüşünü gelecek kuşaklara aktaran, kültürel değerlerin taşıyıcısı çalışmalar gerçekleştirmişlerdir (Arı̆̆, 2018, s. 19).

Kente şekil veren eski ve yeni bütün mimari ve sanatsal uygulamalar o kentin sadece tarihi hakkında bilgi vermekle kalmaz, kentin genel kimliği, toplumu oluşturan bireylerin entellektüel donanımları, refah seviyesi, eğitim yapısı, çevre duyarlılı̆̆ gibi pek çok önemli konuda duruşunu gösterir. Var olan kültür varlıklarına sahip çıkıp onları sonraki nesillere aktarma bilincine sahip kentlilerin meydana getirdikleri kentlerde aidiyetin daha güçlü olduğundan söz edilebilir. Bu, kentsel belleği oluşturan öğelere veya bir kenti kent yapan sosyo-kültürel değerlerine sahip çıkma bilinci ile açıklanabilir. Sivil yapılar, anıtlar, dini yapılar, mühendislik yapılar, korunma altına alınmış doğal yapılar, heykeller, sanat eserleri, müzeler, meydanlar vb. taşınır ve taşınmaz kültür varlıkları toplumun ortak kentsel belleğini oluşturan kültür varlıkları olarak değerlendirilebilinir.

\section{Mimari Bir Unsur Olarak Yüzey Seramikleri}

Seramiğin temel malzemesini kil oluşturmakta ve en yalın haliyle pişmiş toprak olarak ifade edilmektedir. Kimi kaynaklara göre ortaya çıkış tarihi, neredeyse insanlığın tarihiyle yaşıt kabul edilen seramik, medeniyetin erken dönemlerinde insanlığın günlük hayatına girmiş ve günümüze kadar kesintisiz olarak kullanımını sürdürmüştür. Ateşi kontrol etmeyi başardıktan sonra insanın izlerine rastlanılan her yerde seramiğin de izlerine rastlanmıştır. Tarih boyunca farklı biçimlerde ve işlevlerle insanın günlük yaşamı içinde yerini almış ve medeniyetlerin gelişim çizgisi içinde daima varolmuştur. Mutlu'ya göre; seramik çağlar boyunca uygarlığın gelişimine 1 şı tutmuş, yer aldığı toplumun ekonomik, siyasal ve kültürel gelişiminin bir göstergesi olmuştur. Seramik üretimi; insanın uygarlığa yapmış olduğu en eski ve en kalıcı katkılardan biri olarak kabul edilmektedir. Bu anlamda seramik; geçmişimizi daha iyi anlayıp değerlendirebileceğimiz bilgi ve kaynakları günümüze taşımasıyla önemli 
bir görev üstlenmektedir. Seramiğin gelişimi, ona şekil veren toplumun sosyo kültürel ve ekonomik evreleriyle paralellik taşımaktadır. Bu nedenledir ki seramik, döneminin ve ait olduğu uygarlığın sanatına, kullandığı tekniklere ilişkin eşsiz ipuçları veren en değerli tarihi belgeler arasında yer almaktadır (Mutlu, 2007, s. 71).

Tarih boyunca insanların seramiği mimari bir eleman olarak türlü şekillerde kullandıkları bilinmektedir. Kilin kolay temin edilebilir ve rahat işlenebilir bir malzeme oluşu ve ısıya dayanıklı ve görece sağlamlığının bunda payı büyüktür. Sinemoğlu'na göre; insanlığın bilenen tarihinde, ilk mimari seramik elemanlar kerpiçler olarak kabul edilmektedir. İlk örneklerini mimarlık sanatının henüz ilk gelişme alanı olarak kabul edilen Çatal Höyük'te konut yapımında görmek mümkündür (Sinemoğlu, 1984, s. 229). Bir başka kaynakta ise; M.Ö. 4000 yıllarında Mezopotamya'da Sümerlerin yapılarında ve kanalizasyon şebekelerinde seramiği kullanarak seramik-mimari ilişkisinin ilk örneklerini temellendirdiklerinden bahsedilmektedir (Özbay, 2014: 4). Yaşam alanlarının sıvanması ile başlayan serüven zamanla sırsızsırlı tuğla üretimi, çini, fayans, mayolika gibi tekniklerin geliştirilerek kullanılmasıyla devam etmiştir. "Canlı renk ve sağlamlıkta pişmiş tuğlanın ortaya çıkışı MÖ 4. yüzyılı bulur. Mısır ve Mezopotamya'da yapıların yüzeylerini dış etkilerden korumak ve süsleme amacıyla kullanılan renkli tuğlalar bu anlamda ilk seramik pano örnekleri olarak kabul edilebilir" (Kaya, 2018, s. 43). Seramik bazen yapı ve izolasyon malzemesi, çatı kaplaması bazense tamamlayıcı bir mimari öge veya dekoratif bir eleman olarak mimaride kullanımıyla karşımıza çıkmaktadır. Mimari bir unsur olarak iç ve dış mekânlarda yüzeyde kullanımı en sık karşılaşılan türüdür. Tarih boyunca bazen alçak ya da yüksek rölyefler biçiminde, bazen mozaik şeklinde, klasik veya modern panolar halinde, kimi zaman resimsel ögelerin yansitılması şeklinde sırlı ve sırsız türlü biçimlerde uygulama alanı bulmuştur. Yüzey seramikleri antik tiyatrolardan dini mekânlara, mezar yapılarına, saraylardan, çeşmelere, kent mobilyalarına kadar geçmişten günümüze kadar gelmiş günümüzde de çağdaş mimarinin pek çok örneğinde iç ve dış mekânlarda tasarımın önemli bir parçası olmaya devam etmektedir.

Yüzey seramiklerinin mimari yapılarda kullanımının kent kimliğine yüklediği anlamı vurgulamak adına dünyanın farklı bölgelerinde çarpıcı örnekler gösterilebilir. Bunlardan yüzey üzerine sırlı tuğla kullanımının en görkemli örnekleri ile günümüzde Irak toprakları içinde yer alan Antik Babil şehrinin surları üzerinde bulunan İştar Kapısı ve Tören Yolu bu anlamda verilebilecek en önemli örneklerdendir.

Antik dönemde Mezopotamya'nın en büyük şehri ve başkenti olarak bilinen Babil Şehri'nin tarihi M.Ö.3. bin yıla kadar uzanmaktadır. Günümüz Irak topraklarında bulunan Babil antik kentinde 1899 yıllarında başlayan kazılarda ortaya çıkmış olan İştar Kapısı ve Tören Yolu, M. Ö. 604-562 tarihleri arasında II. Nebukadnezzar tarafından sırlı tuğlalarla inşa edilmiş en büyük yapılardandır. Alman arkeolog Robert Koldewey'in 1899'da başlattığı kazılarla gün 1şığına çıkan parçaların bir bölümü ile yeniden inşa edilmiş olan bu kapı, günümüzde Staatliche Museen Zu BerlinVorderasiatisches Museum'da sergilenmektedir. Kazılarda ortaya çıkarılan özgün malzemenin diğer bölümü günümüzde İstanbul Arkeoloji Müzesi Müdürlügü̈'nde bulunmakta ve kısmi olarak sergilenmektedir (Noei, 2018, s. 3).

İştar Kapısı'ndan kuzeye doğru uzanan Tören Yolu da aynı derecede muhteşem tasarlanmıştır. Renkli sırlı kabartmalı tuğlalar mavi ve yeşil-turkuaz sırlı bir alt zemin üzerine vahşi aslan tasvirleriyle donatılmıştır. Aslanlar cennetin hanımı ve ordunun koruyucusu olarak tapınılan tanrıça İştar'1n sembolüdür (Noei, 2018, s. 36).

$\mathrm{Bu}$ yap1 döneminde hem antik şehrin hem de krallı̆̆ın en önemli simgelerinden biri olmuştur. Günümüzde de şehrin en ilgi çekici müzesinde yer alması sebebiyle Berlin kentinin sembolü haline gelmiştir. Almanların en önemli turistik noktalarından biridir (Görsel 1-2). 


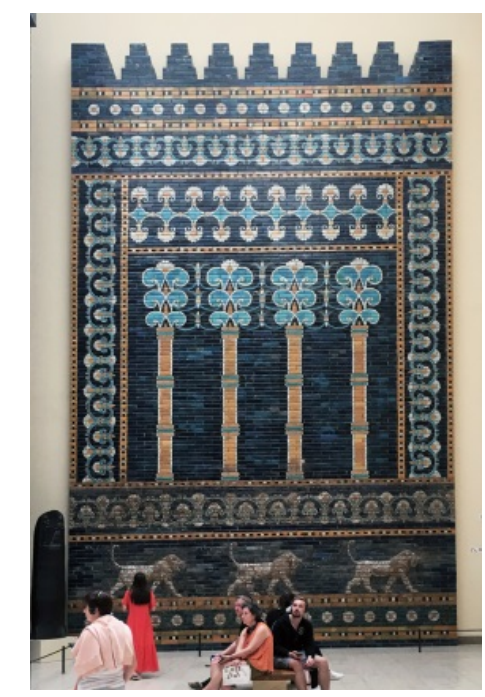

Görsel 1. Taht Odası'ndan bir bölüm, M.Ö 604-562 / Throne room-Staatliche Museen Zu Berlin Vorderasiatisches Museum.

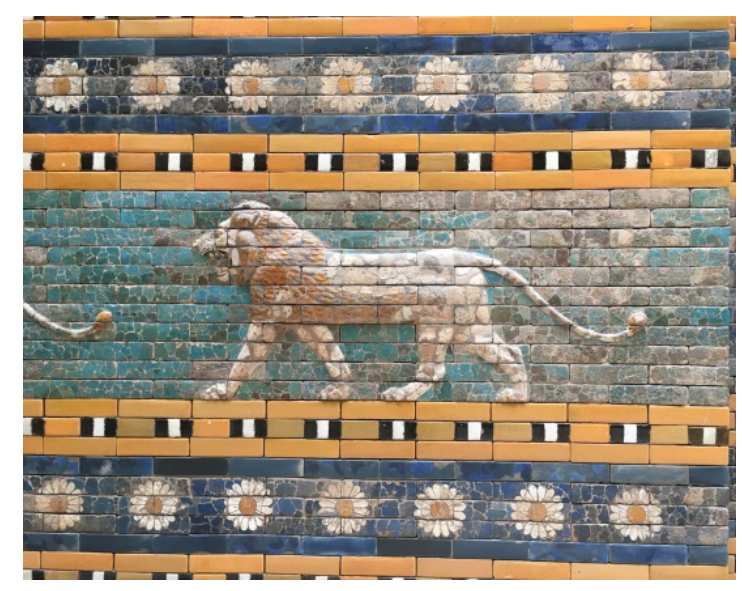

Görsel 2. Işstar Kapısı-tören yolu-ayrıntı, M.Ö 604-562 / Ceramonial way Staatliche Museen Zu Berlin-Vorderasiatisches Museum.

Yüzey seramiklerinin mozaik uygulamalar halinde mimari yapılarda hayat bulduğu çarpıcı örnekleri İspanya'da görmek mümkündür. Mimar Antonia Gaudi'nin (1852-1926) tasarladığ1 gerçeküstücü ve özgün yapılarının bütün veya kısmi olarak yüzeyleri seramik mozaiklerle kaplıdır. Organik mimarlığın güçlü bir savunucusu olan mimar, endüstrinin getirdiği biçimleri doğaya aykırı bulur. "Özellikle heykelsi bacaları, mimariye kattığı renk faktörü ve seçici malzeme kullanımı dikkat çekicidir. Mimaride ustalık işi olan seramik sanatının, sahip olduğu yaratıcı gücü kullanarak estetik anlamda gelişmiş bir düzeyde kullanmıştır. Barselona'daki Guell Park (1900-1914) Gaudi'nin kendi stilini yarattı̆̆ı ve tarihselcilerden ayrılarak, özgürleştiği ilk yapıttır" (Özbay, 2014, s. 6). Gaudi’nin imzasını taşıyan dünyaca ünlü Sagrada Familia Bazilikası'nın (1883-1926) kubbe kısımlarında yer alan renkli seramik mozaikleri ve Casa Milla (1906-1912) binası da teras altında kullanılan tuğla katener kemer yapısı ve organik formlu balkonları ile Barselona kentinin adeta simgesi haline gelmiş olan önemli seramikmimari birlikteliği örneklerindendir (Görsel 3-4). Bu yapılar Barselona halkı için tarihi değerleriyle, farklılıklarıyla, yaşadıkları gündelik etkileşimleriyle kent belleklerinde derin yer tutmakta ve bunun doğal neticesinde kente duydukları aidiyeti arttırmaktadır. 


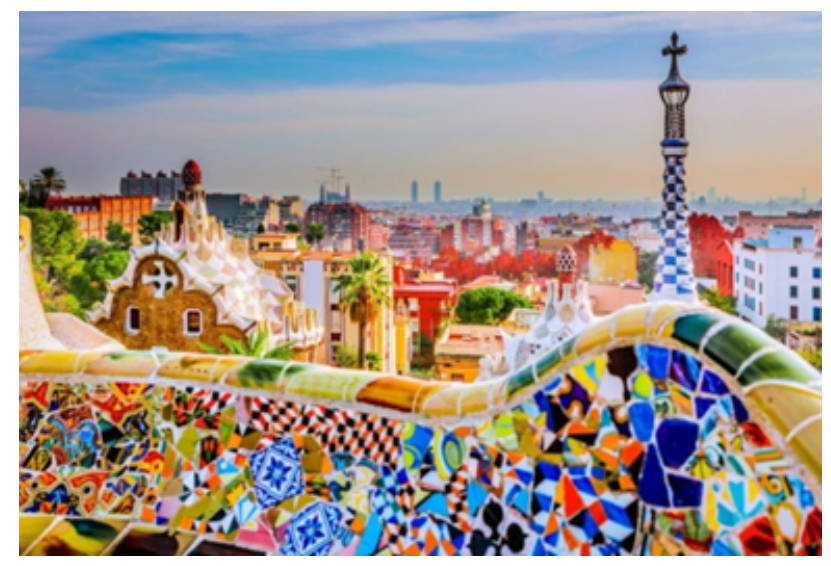

Görsel 3. Antonia Gaudi, 1900-1914, Park Guell Barselona/ Park Guell Barcelona

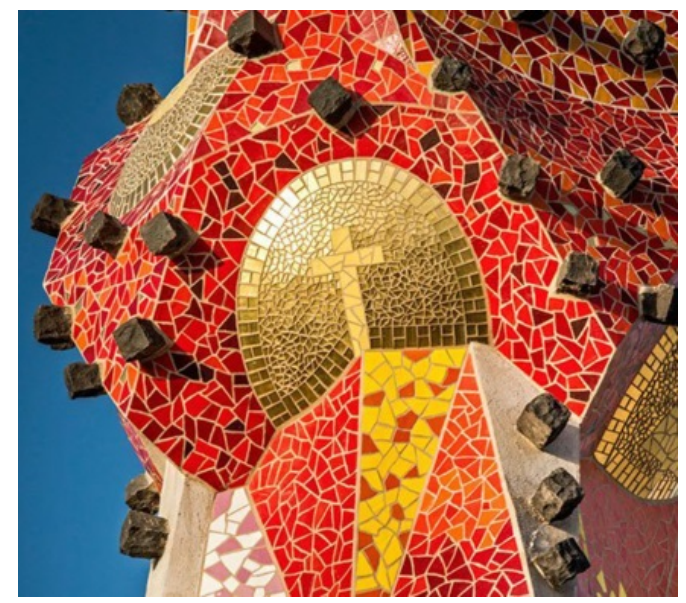

Görsel 4. Antonia Gaudi, 1883-1926, Sagrada Familia Bazilikası'ndan detay/La Sagrada Familia

Rusya'nın köklü tarihinden ve özellikle Avrupa ile yakın etkileşiminden kaynaklanan seramik geleneğiyle kentlerde iç ve dış mekân yüzey uygulamalarıyla sıklıkla karşılaşılmaktadır. Repina'nın (2017) konuyla ilgili araştırmalarından şu bilgilere ulaşılmaktadır; Moskova ve Yaroslavl gibi kentlerde sırlı ve dekorlu yüzey karoları 16. ve 17. yüzyıllarda üretilmiştir. St. Petersburg, Rusya'nın zengin sanatının ve Avrupa mirasının organik bir entegrasyonunu yansıtmaktadır ve bu geleneğin sürdürülmesi 18.yüzyılı bulmuştur. St. Petersburg'da Menshikov Sarayı kentin önemli sembollerinden biridir ve çağdaşlarından farklı bir örnektir. Dış cephesi sade bir tasarıma sahip olan sarayın iç mekân yüzeyleri mavi-beyaz Hollanda Delf tarzı kobalt sırlı yüzey seramikleriyle kaplıdır. Ayrıca odalarda yüzeydeki seramiklerle uyum içinde tasarlanmış klasik çini sobalar mevcuttur. Sarayın dört odasının duvar ve tavanları 27.810 adet tematik dizilime sahip mavi-beyaz fayanslarla kaplıdır (Görsel 5). Kentin sembolü haline gelen diğer önemli yapılara bakıldığında yine yüzey seramiklerinin varlığı dikkat çekmektedir. Yapımı 24 senede tamamlanan, yüzeyi tuğla ve sırlı mozaiklerle kaplı Savior on Blood kilisesi (Church of the Saviour on the Spilled Blood) (Görsel 6), mayolika işçiliği ile öne çıkan Naval Kathedrali (Naval Cathedral of St. Nicholas in Kronstadt), giriş kapısındaki renkli sırlı alçak rölyefler ile Deneysel Tıp Enstitüsü Kütüphanesi St. Petersburg şehrinin simgesi haline gelmiş, köklü geçmişi ile geleceğe uzanan, kentin önemli yapılarıdır (Repina, 2017, s. 1-5). 


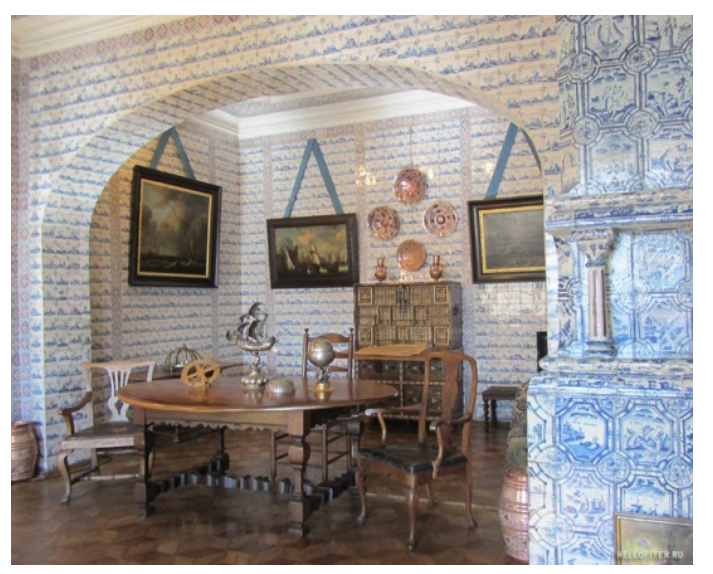

Görsel 5. Menshikov Sarayl, 1710, St.Petersburg, Rusya/ Menshikov Palace

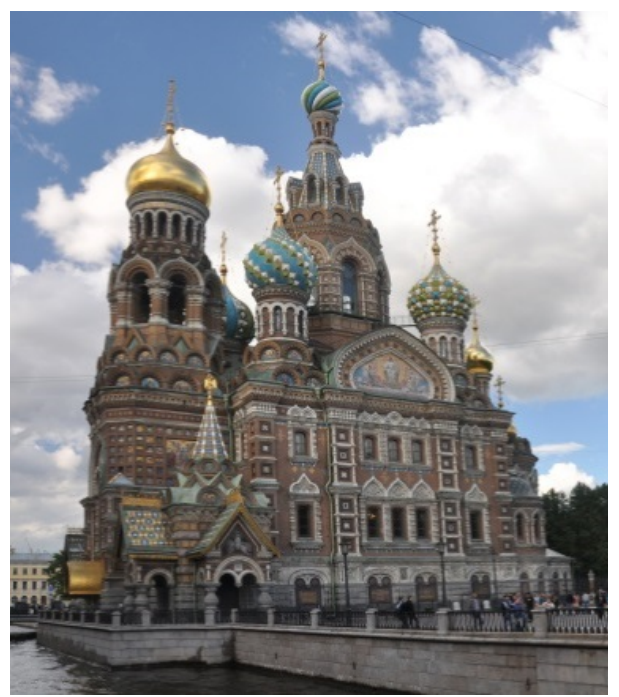

Görsel 6. Kanlı Kilise (Yeniden Diriliş Kilisesi), 1881, St. Petersburg, Rusya/ Church of the Savior on Blood.

Dünyada farklı kültürlere ait, farklı dönemlerde üretilmiş ve kentlerin simgesi haline gelmiş iç ve dış yüzeylerde seramik kullanımını daha çok sayıda örneklerle zenginleştirmek mümkündür. Zengin köklü tarihi ve eşsiz üretimleriyle Pers kültürünün mimariye yansıdığı İran mozaik ve seramik işçiliği dini yapıları dünyada buna önemli bir örnektir. Seramik ve çini sanatına pek çok tekniği katan yine İranlılardır. Parlak canlı renklerde mozaik karolarıyla, lüsterleriyle, geometrik dizilimleriyle, stilize yazı tasarımlarıyla, eşsiz tuğla işçiliğiyle özellikle dini yapılarda kendini gösterir.

Türkiye'de kimi üretimlerde İran'la benzerlik gösteren çini geleneği dini yapıların iç ve dış yüzey kaplamalarında yoğun bir biçimde kendini göstermekte ve bu yapıların iç ve dış yüzeylerinde kullanılmış olan çini kaplamalar köklü Türk tarihini geleceğe taşımaktadır.

Hollanda-Delft, Çin porseleninin Avrupa'ya girip, tanınmasında, Avrupa zevk ve beğenisi ile harmanlanarak üretilmesinde en önemli merkezlerden biri olmuştur. Ülkenin en önemli sembollerinden biri olmakla beraber, Hollandalıların sahiplendikleri en büyük kültürel unsurlardan biri Delft mayolikalarıdır.

Porselenin ana vatanı Çin, farklı hanedanlık dönemlerinin yansıtıldığı sembolik anlatımlarıyla hem iç ve dış mekânlarda yüzeyde hem de yapıların tavan ve çatı seramiklerinde yoğun olarak kullanılmakta ve bu hali ile kent silüetine hâkim olmaktadır (Görsel 7). Çin'de mitolojik kahramanların, sembollerin, insan ve hayvan figürlerinin yapılarda kullanımı çok yaygın bir gelenektir. Alçak ve yüksek kabartmalar, 
sır alt1-sır üstü fırça işi yüzey karoları da yine sıklıkla kullanılan ve kentlerde hemen hemen tüm yapılarda karşılaşılan karakteristik unsurlardır. Shanxi Eyaleti, Datong'da yer alan ve "Dokuz Ejder Duvarı" adıyla bilinen sırlı seramik duvar panosu $45.5 \mathrm{~m}$ x 82 x $2.02 \mathrm{~m}$ ölçüleriyle en büyüklerindendir. Ming Hanedanlığı'nın (1368-1644) ilk imparatoru Zhu Yuanzhang'ın 13. oğlunun köşkünün önünde bulunmaktadır (Görsel 8) (Asya kültürü, 2010).

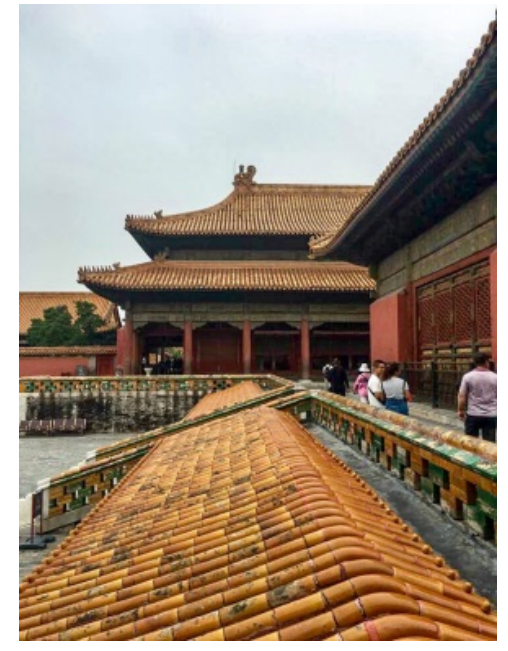

Görsel 7. Geleneksel Çin çatı mimarisi/ traditional Chinese roof ceramic tiles

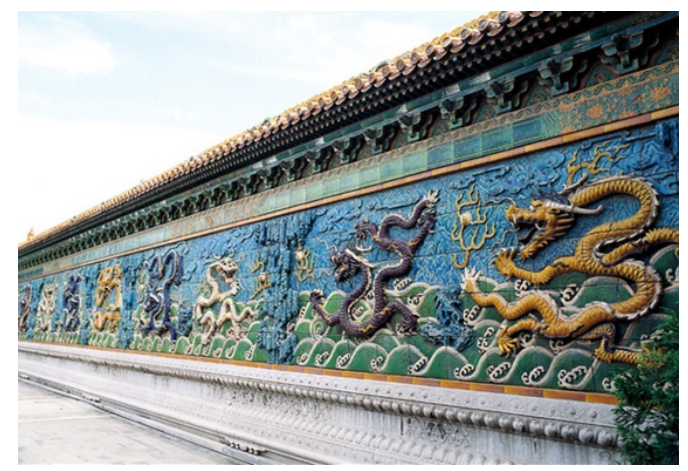

Görsel 8. Ming Hanedanlı̆̆l, 1368-1644, Dokuz Ejder Duvart/Nine Dragons Wall

\section{Portekiz Yüzey Seramikleri ve Porto Sao Bento Tren İstasyonu}

Dünyada farklı dönemlerde pek çok yerleşim merkezlerinde kent dokusuna önemli katkıları olan seramik karolara önemli bir örnek de geleneksel Azulejos Seramikleridir. “Azulejo" İspanya ve Portekiz'de üzeri opak sırla kaplı terracotta fayansı tanımlayan bir terimdir. Azulejo, kelime anlamı ile "parlatılmış taş" anlamına gelen Arapça kökenli bir sözcüktür. Mağribiler tarafindan İber Yarımadası'na getirilmiş bir kelimedir. Bu anlamda kullanılan karolar Hollanda, İspanya, İtalya, Türkiye, İran ve Fas'da da kullanılmaktadır. Azulejos karolar 13. yüzyıldan beri sıklıkla duvar panellerinde, çeşmelerde, kaldırımlarda, tavanlarda, tonozlarda, banyo veya şöminelerin yüzey süslemelerinde kullanılmıştır. $\mathrm{Bu}$ çinilerin büyük dekoratif panellerde kullanımı, Brezilya'dan Hindistan'a Portekiz kültürünü etkileyen bir kültürel miras olarak kabul edilebilir. En eski örnekleriyle 13. Yüzyılda karşılaşılan Azulejos seramiklerinin en yetkin örneklerine 17. yüzyılda Portekiz'de, özellikle Lizbon ve Porto kentlerinde rastlanılmıştır (Pereira, De Lacerda-Aroso, Gomes, Mata, Alves \& Colomban, 2009, s. 79). Bu tarz seramiklerin üretimleri öncelikle Portekiz'de manastır ve kiliselerin duvar yüzey kaplamalarıyla başlamıştır. Farklı dekor özellikleriyle üretilen bu seramiklerde yeşil, sarı, kahve, mavi renkler dikkat çeker. Süreç içerisinde geometrik formlar, doğal çiçek, yaprak betimlemeleri, kabartmalar, figürler, 
manzaralar, gemiler, dinsel motifler ve ikonlar gibi pek çok farklı biçimlerde, renk ve dokularda işlenegelmiştir. En gösterişlileri Delft işi mayolikaların benzeri, firça dekorlu mavi-beyaz olanlarıdır.

Erken dönem seramik karolarının büyük bir kısmı Mağribi kültürü etkili desenler, iç içe geçmiş motifler, eğrisel çizgiler, dantel gibi işlemeler ve döngüsel, geometrik veya bitkisel bezemelerden oluşmaktadır. Portekizliler tüm yer ve duvar zeminini hiç boşluk olmaksızın kaplayan Mağribi ülkelerin kültürel zevkini yansıtan dekorasyonları korumuşlardır. Çini karoların kullanımı Avrupa kıtasından Atlantik adalarına kadar ve geçmişte Portekiz'in kolonilerinin yer aldığı başta Brezilya olmak üzere, 15. yüzyılın sonundan günümüze dek yayılım göstermiştir. Bu yoğun kullanım özellikle Hollanda'dan ya da Antwerp, Seville, Talavera de Reina ve Urbino gibi bölgelerdeki bazı benzer üretimlerle karşılaşılmasının nedenini açıklamaktadır (Meco, 1994, s. 5).

17. yüzyıl boyunca Portekiz azulejo seramik karolarında, kobalt mavisinin kullanıldığı özel bir boyama tarzının gelişmesi dikkat çekmektedir. Bu üretimler izlenimci etkisi ile soyut estetik değerler barındırmaktadır. Bu karolar dekoratif işlevlerinin ötesinde Portekiz kültürünün en önemli sanatsal ifade formlarından birini de ortaya koymaktadır. Azulejo seramik karolar Portekiz menşeili olmamalarına rağmen, hem iç hem dış mekânlarda, geniş bir kullanım alanıyla, kesintisiz bir şekilde 500 yılı aşkın süredir gelişerek kullanımını sürdürmektedir (Mitchell, 2016, s. 348). Bu kullanım yoğunluğu, seramik karoların Portekiz sanatının temsilcisi olduğunu ortaya koymaktadır. Azulejo seramik karoların gelişiminde ilk Mağribilerin ortaya koyduğu desenlerden, Avrupa Rönesans ve Gotik çiçek ve hayvan betimlemelerine, Hint kumaş motiflerine ve Doğu etkilerine kadar pek çok farklı kültürden etkilenildiği görülmektedir. 18.Yüzyılın başları 'Azulejo'nun Altın Çağı' bir diğer değişle 'Ustalar Çağı' olarak anılmaktadır. Portekiz sırlı seramikleri için Portekiz ve sömürgelerine özellikle de Brazilya olmak üzere yoğun bir talep bulunmaktadır. Manastırlar, saraylar ve hatta evlerin iç ve dışları birçok coşkulu Barok elemanları barındıran azulejos karolarla kaplanmıştır (Meco,1994, s. 49).

19. yüzyılın sırlı seramik karolarla ilgili en dikkate değer anıtsal yapıtı, büyük üstat Jorge Colaço (18681942) tarafindan gerçekleştirilen 20.000 parça el boyaması kalaylı mavi-beyaz sırlı azulejos karodan oluşan Porto merkez Sao Bento tren istasyonudur. Bir tuval ressamı ve karikatürist olan Jorge Colaço, sanat eğitimini Lisbon, Madrid ve Paris'de tamamlanmıştır. İlerleyen dönemlerde özellikle büyük ebatlı seramik panoların yapımında, karo üzerinde firça ile resmetme konusunda uzmanlaşmıştır. İlk karo 13 Ağustos 1905 y1lında monte edilmiştir. Colaço'nun çalışması 11 senede tamamlanmıştır (Görsel 9) (Jorge Colaço, 2015). İstasyonun girişteki büyük salonun sol cephesinde Portekiz tarihinde önem teşkil eden büyük savaşlardan sahneler canlandırılmaktadır. Bunlardan en görkemlisi Büyük Valdevez Savaşı' dır (Görsel 10).

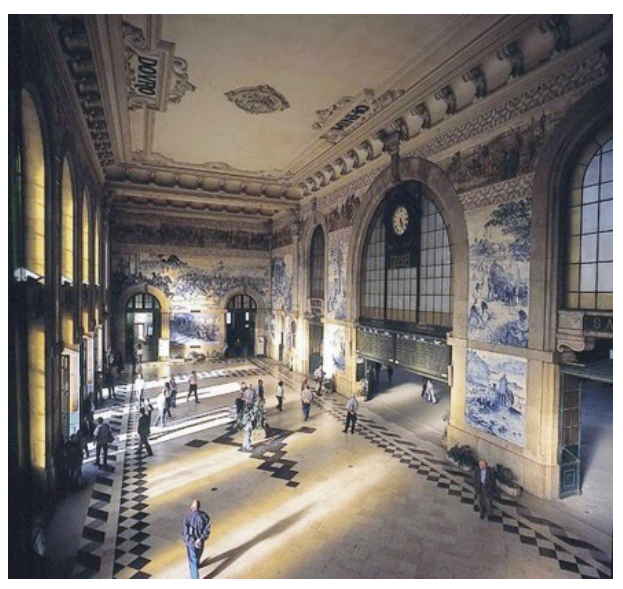

Görsel 9. Jorge Colaço, 1868-1942, Porto Sao Bento merkez tren istasyonu giriş salonu/Porto center railway station entrance hall 


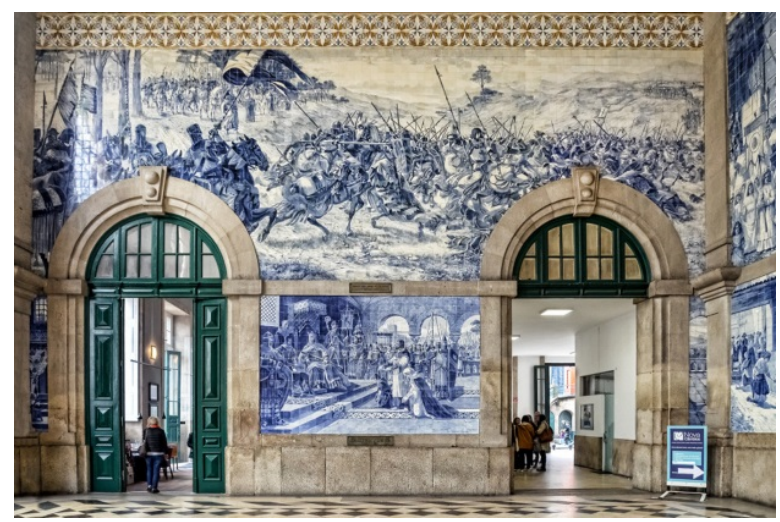

Görsel 10. Jorge Colaço, 1868-1942, Porto Sao Bento merkez tren istasyonu Büyük Valdevez Savaşı'nın canlandırıldı̆̆ı ana duvar/ Porto center railway station main wall of the Great Valdeves War

Salondaki bordürlerde Portekiz'den seçilmiş deniz kıyısı manzaraları resmedilmektedir. Savaş sahnelerinin işlendiği alanların üst bölmelerinde yer alan frizlerde kronolojik sırasıyla Portekiz'in ulaşım tarihine 1şık tutan resimlemeler yer almaktadır. Bunlar mavi-beyaz değil çok renkli, hareketli resimsel betimlemelerdir. Bu iki farklı alan birbirlerinden mavi, kahverengi ve sarı geometrik bezemelerle ayrılmaktadır (Görsel 11). Daha alt kısımlarda yer alan kompozisyonlarda dönemlerin krallarının taç giyme, evlilik, ata binme, doğum gibi önemli kutlama seramonilerinin betimlendiği resimler betimlenmiştir (Görsel 12) (Carvalho, 1986, s. 11). Bu haliyle istasyonun ana duvarlarının kendi içinde panellere ayrıldığı ve böylece katmanlı kompozisyonlar sergilenebildiği söylenebilir.

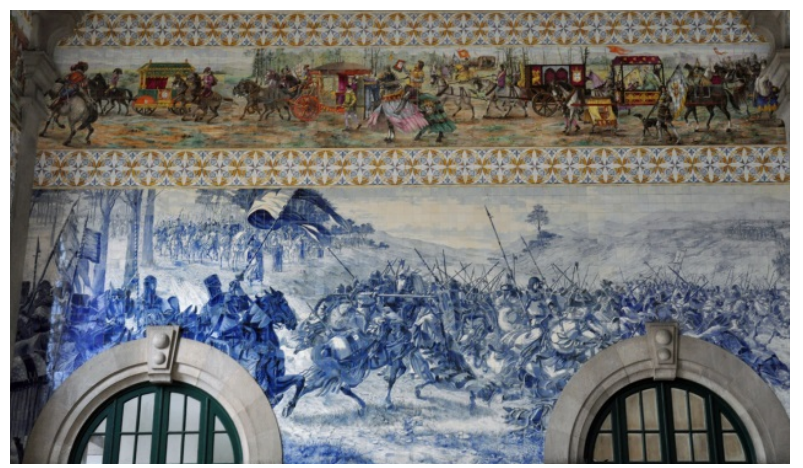

Görsel 11. Jorge Colaço, 1868-1942, Büyük Valdevez Savaşı'nın canlandırıldığı ana duvar renkli üst frizler/colourful top friezes of main wall of the Great Valdeves War

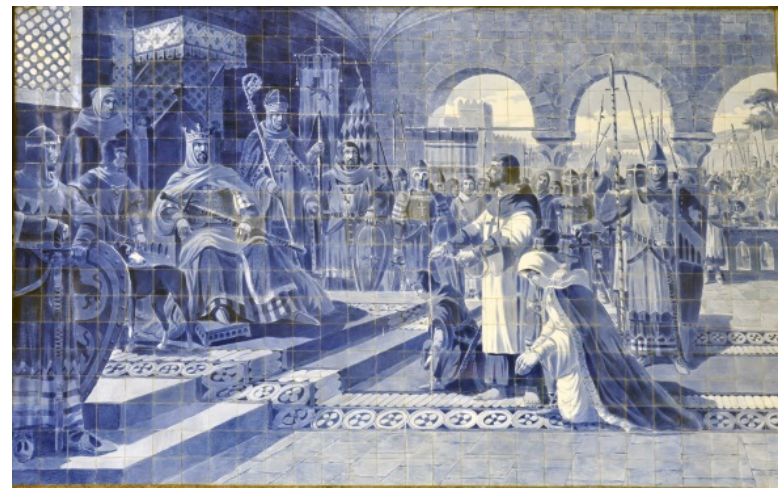

Görsel 12. Jorge Colaço, 1868-1942, Porto Sao Bento merkez tren istasyonu giriş salonu dini motifler ve taç giyme töreni/Porto center railway station entrance hall religious motifs and coronation ceramonies 
Alt panellerde dini temalı resimlerle tarım hayvanc1lıkla ilgili betimlemeler bulunur. Ayrıca bayramlar, halk gelenekleri, gündelik eğlenceler, pazar yerleri, şenlikler gibi konular da tüm ayrıntılarıyla işlenen konulardandır (Görsel 13). Ortada merkezdeki paneller ise Portekiz için önemli olan dört iş alanını temsil etmektedir. Bunlar; üzüm hasatı ve üzüm bağları, gemicilik ve ticaret, rüzgâr ve rüzgâr değirmenlerinden oluşmaktadır (Görsel 14,15). Bunların üzerinde romantik sahneleri tasvir eden daha küçük madalyonlar yer alır. Altlarında trenlerle, demir yollarıyla ilgili hikayelerin betimlendiği sahneler ve renkli saat sembolleri bulunur (Görsel 16) (Carvalho,1986, s. 12).

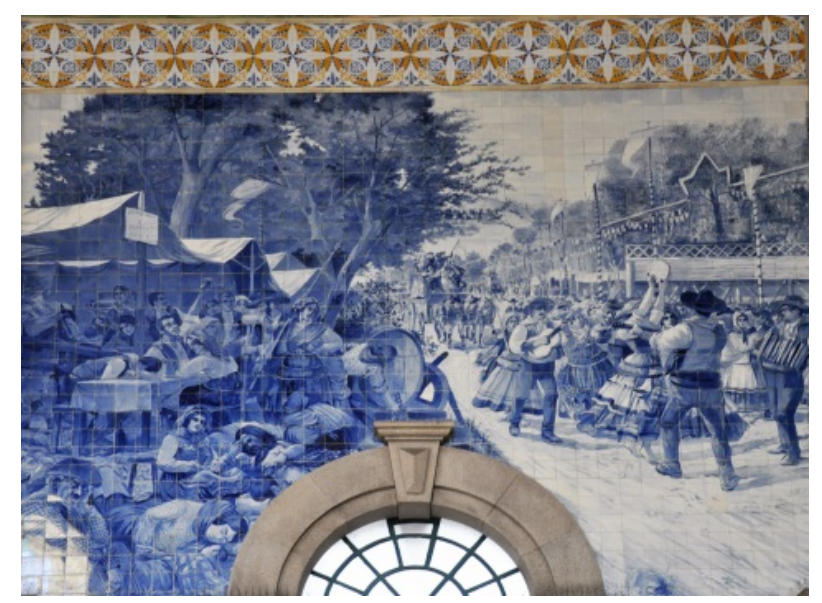

Görsel 13. Jorge Colaço, 1868-1942, Porto Sao Bento merkez tren istasyonu, günlük halk eğlencelerini gösteren betimlemeler/ descriptions of daily public entertainment

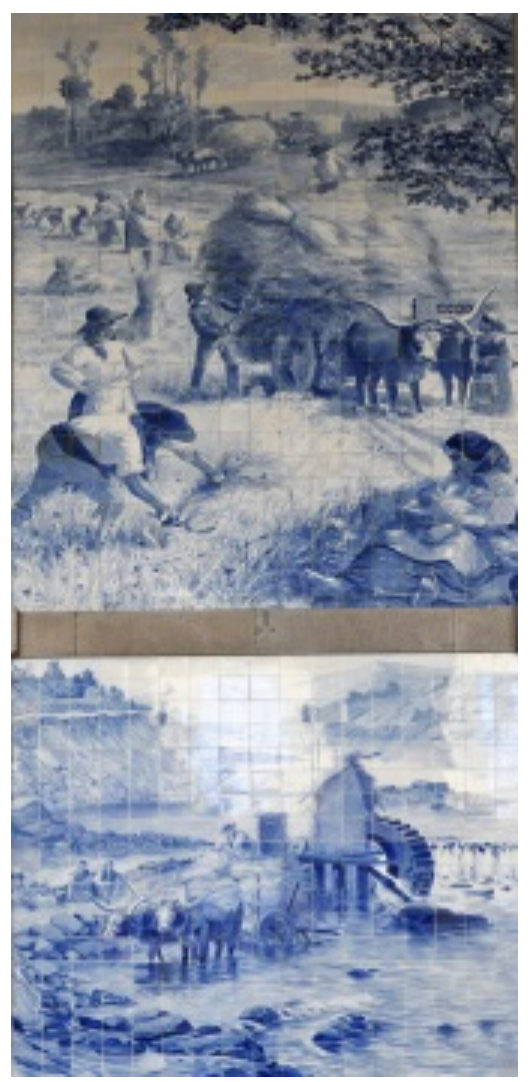

Görsel 14. Jorge Colaço, 1868-1942, Porto Sao Bento merkez tren istasyonu, hayvancllıkla ve rüzgâr değirmenleriyle ilgili betimlemeler, descriptions of animal farming and wind mills 


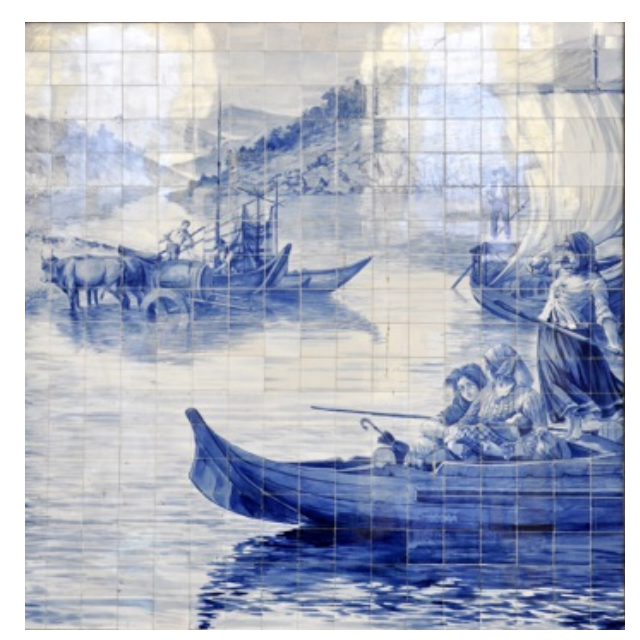

Görsel 15. Jorge Colaço, 1868-1942, Porto Sao Bento merkez tren istasyonu, denizcilikle ilgili resimli karolar/ceramic wall panels about maritime

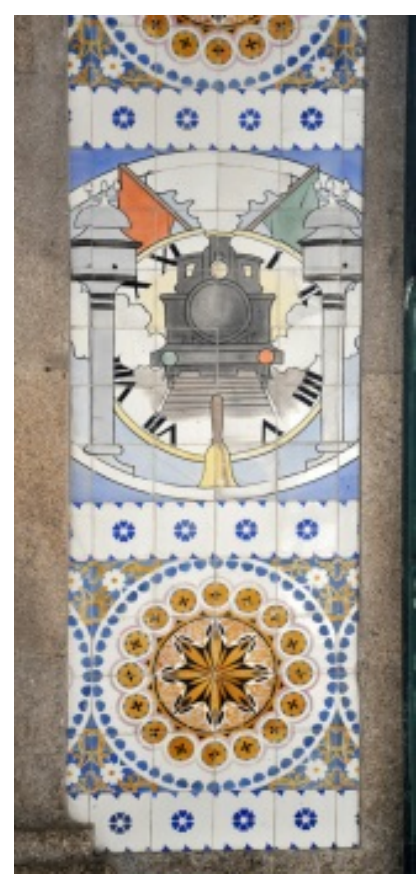

Görsel 16. Jorge Colaço, 1868-1942, Porto Sao Bento merkez tren istasyonu, saat ve renkli madalyonların işlendiği sirl yüzey karoları / ceramic wall panels about clocks and multicolour symbols

\section{Sonuç}

Jorge Colaço'nun Porto Sao Bento merkez tren istasyonu için yaptığı seramik karolardan oluşan yüzey panoları yanlızca seramik sanatının teknik ve estetik alanında hayranlık uyandırmakla kalmaz, kavramsal olarak da çok derin anlamlar barındırmaktadır. Bu istasyon sanatsal, kültürel, sosyolojik, mimari pek çok farklı açılardan önem taşımaktadır. Sao Bento istasyonu duvar seramikleri Portekiz'de kentleri adeta sarıp sarmalayan ve onlara ayrıcalıklı bir özellik veren kent yüzey seramiği geleneğinin Klasik ve Romantik anlamdaki son uygulamalarıdır. Bu tasarımlar tarihçilerce Portekiz tarihini ve başarılarını resmederek anlatan Romantik ve Klasik anlayışlardaki son azulejos üretimler olarak kabul edilmektedir. Daha sonra yapılan seramik karo üretimlerde ya geçmiş geleneksel üretimlerin tekrarları 
yapılmıştır ya da modern üretimlerle bambaşka bir alana yönelinmiştir. Bu açıdan bir devrin kapanışı olarak da nitelendirilirirler. Tarihsel temaların yanı sıra resimli karo betimlemelerinde etnografik anlatımlar, manzaralar ve gündelik yaşama dair sahneler de bulunmaktadır. Bu hali ile büyük bir belgesel nitelik taşımaktadır. İstasyon, Porto'nun tam merkezinde, tarihi bölgede yer almaktadır. Bir gün içerisinde yerli ve yabancı yüzlerce, binlerce insanın geçiş noktasında bulunarak aslında Portekiz sanatını, tarihini, kültürünü durmaksızın insanlara ileten zamansız bir kültür elçisidir. Bu yaşayan duvarlar, yabancılar için kentin tarihini anlatan ve geçmişine 1şı tutan bir belgesel olurken, Portekizliler içinse, geçmişleriyle devamlı bağlantı halinde olmalarını sağlayan güçlü bir bağ konumundadır.

İstasyonlar kimi zaman insanların uzun saatler bekledikleri yerler olduklarından, yolcular en ince ayrıntılarına kadar bu sanat şaheserini inceleme firsatı bulabilmektedir. Porto'nun kalbinde yer alan bu istasyon bir anlamda kentli yolcuları Portekiz'in şanlı geçmişine götürerek kökleriyle tekrar bağlantı kurmasını sağlar. Yaşadıkları toprakların hangi savaşlarla nasıl kazanıldığını hatırlatır. Gerek istasyonun mimarisiyle, gerekse duvarlarını kaplayan mavi-beyaz seramik anlatımlarla yolcuları geçmişe götüren ve geleceğe taşıyan bir zaman kapsülü gibidir. Bütün bu özellikleri göz önünde bulundurulduğunda Porto Sao Bento tren istasyonunun Portekiz için kent belleğini oluşturan çok önemli bir merkez olduğunu söylemek yanlış olmayacaktır.

Portekiz özelinde azulejos duvar karoları örneğinde görüldüğü üzere, yüzey seramikleri kamusal alanlarda pek çok binanın duvarını süsleyerek, kentlere ayrı bir kimlik katmaktadır. Seramik malzeme yapısından kaynaklı olarak mimariye ve dolayısıyla da kentlere sıcak ve doğal bir görünüm katar. Seramiğin mimaride yüzeyde kullanımı sırlı ya da sırsız, alçak ya da yüksek rölyefli, geometrik veya gerçekçi resimsel betimli vb. farklı çeşitlerde olabilmektedir. Bu kullanım çeşitliliği seramik malzeme ile tarih boyunca her seferinde daha da farklı sonuçlar alınmasını olanaklı kılmıştır. Portekiz'de kentlere ayrıcalıklı bir kimlik kazandıran bu özel seramik üretimler, günümüzde modern bir anlayışla yorumlanarak mimari mekânlarda iç ve dış yüzey kaplamalarında kullanımını sürdürmektedir. Çağımızın kentsel gelişimi karo tasarımlarında da yeni malzemelerle ve yeni platformlarda türlü yenilikleri beraberinde getirmiştir. Yeni nesil mimarlar yeni nesil genç sanatçıları çağdaş kentsel projeler oluşturmak için görevlendirmektedir. Sanatçılar kille beraber diğer farklı malzemelerin plastikiyetini keşfetmeye başlamışlardır. Yeni Lisbon metrosu sanatçılara anıtsal kompozisyonlar sergileyebilmek için geniş olanak sağlamaktadır. Günümüzde Portekiz'de geleneksel desenlerin üretimini yapan pekçok atolye hala vardır ve eski, antik karoların üretimi ve satışı devam etmektedir.

Kentleri oluşturan, onu diğerlerinden farklı kılan belirli bir kimlik kazandıran etkenler yanlızca mimari yapılar, sokaklar, caddeler gibi fiziki özelliklerle sınırlı değildir. Kentler, içinde yaşayan toplumların kendine has kültürel, düşünsel, tarihi ve coğrafi özellikleri ile şekillenerek yalnızca bir "yer" olmanın çok ötesinde anlamlar kazanırlar. İşte bu noktada insanın-mekânla kurduğu bağ ve yüklediği anlam belirleyicidir. Sanat ve yapıt bu durumda geçmiş- bugün ve gelecek arasında insan ve kent ilişkisindeki bağın kurulmasında ve kültürel aktarımın sağlanmasında büyük bir rol oynamaktadır. Bu bağlamda bir kent belleği unsuru olarak mimaride iç ve dış yüzeylerde seramiğin kullanımının kökleri çok eskilere dayanan, insan ve kent etkileşimini arttıran, kültürel bağları sıkılaştıran ve kent aidiyetini pekiştiren önemli bir unsur olduğu söylenebilir. Buradan yola çıkarak dünya kentlerinden pek çok örnek arasından Porto Sao Bento merkez tren istasyonu bir kent belleği unsuru olarak yüzey seramiklerinin öneminin vurgulanacağı en önemli örneklerden biri olarak seçilmiştir.

\section{Kaynakça}

Al, M. (2011). Kentte bellek yıkımı ve kimlik inşası-palimpsest: Ankara Atatürk bulvarı bağlamında bir inceleme. İdeal Kent, 4, 22-36. 
Alpak, E. M., Düzenli, T., Eren, E. T. (2018). Kent kimliği ve kullanıcıların bağl1lık duygusu üzerindeki etkisi: Trabzon kenti örneği. Akademik Sosyal Araştırmalar Dergisi, 6 (64), 519-528. Erişim adresi:https://www.researchgate.net/publication/322654937_kent_kimligi_ve_kullanicilarin_ba glilik_duygusu_uzerindeki_etkisi_tarabzon_kenti_ornegi

Arı̆̆, T. (2018). Kent kimliğinin oluşmasında mimari ve sanatsal uygulamaların etkisi. Sanat Yazıları, $38,15-30$.

Asya kültürü. (2010, 12 Kasım). Erişim adresi: http://www.asean-china-center.org/english/

Carvalho, M. (1986). História da Arte em Portugal (Cilt 11). Lisboa: Publicações Alfa.

Erçoşkun, E. Y., Akünal, Ö. E., Yenigül, S. B., Alkan, L. (2016). Kentlilik bilincini oluşturan göstergeler ve kentlilik bilincini geliştirme yolları: Paradoks ekonomi. Sosyoloji ve Politika Dergisi, 11, 423.

Kaya, E. (2018). Porselen lithophane tekniğinin incelenmesi ve iç mekân duvar panosu olarak uygulanabilirliğinin araştırılması (Yüksek Lisans Tezi). YÖK Tez Merkezi veri tabanından erişildi (Tez No: 511298).

Kültür nedir?. (2017, 25 Mayıs). Erişim adresi: https://www.turkedebiyati.org/kultur-nedir-kulturhakkinda-kultur-anlami/

Meco, J. (1994). The art of Azulejo in Portugal-Portuguese glazed tiles. Lisboa: Bertrand Editora.

Mitchell R. (2016). Portuguese art: Portuguese azulejos, 341-360. Erişim adresi: https://michelangelo.pixelonline.org/files/Manual_of_fine_arts/New\%20Manual\%2012\%20port ugal.pdf

Mutlu, H. S. (2007). Zamanın çarkında Anadolu'da seramik. Anadolu Sanat, 18, 71-75.

Noei, T. A. (2018). Babil-İstar kapısı sırlı tuğlalarının karakterizasyonu ve korumaya yönelik öneriler (Yüksek Lisans Tezi). YÖK Tez Merkezi veri tabanından erişildi (Tez No: 514892).

Olgun, İ. (2009). Kentsel değişim sürecinde kentsel okuma ve bellek ilişkisi (Doktora Tezi). YÖK Tez Merkezi veri tabanından erişildi (Tez No: 256598).

Özbay, B. (2014). Artistik seramik panoların iç mekân tasarımına estetik katkısı (Yüksek Lisans Tezi). YÖK Tez Merkezi veri tabanından erişildi (Tez No: 367896).

Özgen Kösten, E. Y. (2015). Kentsel kimliğin değişen görüntüleri: Eski kent, yeni merkez İzmit. EJournal of New World Sciences Academy, 10 (1), 1-19. Erişim adresi: http://dergipark.ulakbim.gov.tr/nwsasocial/article/view/5000075282

Pereira, M., De Lacerda-Aroso, T., Gomes, M. J. M., Mata, A., Alves, L. C. \& Colomban, Ph. (2009). Ancient Portuguese ceramic wall tiles (azulejos): Characterization of the glaze and ceramic pigments. Journal of Nano Research, 8, 79-88. Erişim adresi: https://www.researchgate.net/publication/250361435_Ancient_Portuguese_Ceramic_Wall_Tile s_Azulejos_Characterization_of_the_Glaze_and_Ceramic_Pigments/download

Repina, Y. (2017). Ceramics in the architecture of St. Petersburg 1-5. Erişim adresi: http://www.icaa.org/en/UploadFiles/Ceramics\%20in\%20the\%20Architecture\%20of\%20St. $\% 20$ Petersburg.pdf

Schulz, N. C. (1971). Existence, space and architecture, praeger. New York, 9, 11-36.

Sinemoğlu, N. (1984). Sanat tarihi. İstanbul: M. Ü. Yayınları. 
The World Trade Organization. (2015, Nisan). Jorge Colaço "Fishing", "Grape Picking” and "Agriculture". The WTO Building Art and Architecture at The Centre William Rappard "Works of Art”. Erişim adresi: https://www.wto.org/english/res_e/booksp_e/wto_building15_e.pdf

Turgay, O. (2009). Mekânin kurgulanmasinda ve algilanmasında "bellek"in belirleyici etkisinin analizi (Sanatta Yeterlik Tezi). YÖK Tez Merkezi veri tabanından erişildi (Tez No: 256593).

Uludağ, K. (2000). Eskişehir kimliğini, kimlik verecek kent soylusunu arıyor. Onbeşgün Dergisi, 4, 45 .

\section{Görsel Kaynakçası}

Görsel 1. Taht Odası'ndan bir bölüm. (Tarihi yapı). (M.Ö 604-562). Throne room [sırlı pişmiş toprak]. Staatliche Museen Zu Berlin-Vorderasiatisches Museum. (Kişisel fotoğraf arşivi).

Görsel 2. İştar Kapısı-tören yolu-aslan detayı. (Tarihi yap1). (M.Ö 604-562). Ceramonial way [sırlı pişmiş toprak]. Staatliche Museen Zu Berlin-Vorderasiatisches Museum. (Kişisel fotoğraf arşivi).

Görsel 3. Antonia Gaudi. (Mimar). Park Guell Barselona/ Park Guell Barcelona [sırlı mozaik]. Erişim adresi: https://skiptheline.tickets/barcelona/park-guell\#prettyPhoto/0/

Görsel 4. Antonia Gaudi. (Mimar). (1883-1926). Sagrada Familia Bazilikası'ndan detay, /Detail of La Sagrada Familia. [sırlı mozaik]. Erişim adresi: http://www.sagradafamilia.org/en/light-andcolour/

Görsel 5. Menshikov Sarayı. (Tarihi yapı). (1710). Menshikov Palace [sırlı dekorlu duvar seramiği]. Erişim adresi: http://www.hellopiter.ru/Menshikovsky_palace_photo_zal_2.html

Görsel 6. Kanlı Kilise (Yeniden Diriliş Kilisesi). (Tarihi yapı). (1881) St. Petersburg, Rusya / Church of the Savior on Blood. [sırlı pişmiş toprak]. (Kişisel fotoğraf arşivi).

Görsel 7. Geleneksel Çin çatı mimarisi/ traditional Chinese roof ceramic tiles. (Kişisel fotoğraf arşivi).

Görsel 8. Ming Hanedanlığı (Tarihi dönem). (1368-1644). Dokuz Ejder Duvarı/ Nine Dragons Wall. [sırlı pişmiş toprak]. Erişim adresi: http://big5.xinhuanet.com/gate/big5/www.asean-chinacenter.org/english/2010-05/27/c.htm

Görsel 9. Jorge Colaço. (Mimar). (1868-1942). (Tarihi yap1). Porto Sao Bento merkez tren istasyonu giriş salonu/ Porto center railway station entrance hall. [sırlı dekorlu duvar seramiği]. Erişim adresi: http://planetportugal.blogspot.com/2011/10/der-bahnhof-sao-bento-in-porto.html

Görsel 10. Jorge Colaço. (Mimar). (1868-1942). (Tarihi yapı). Büyük Valdevez Savaşı'nın canlandırıldığı ana duvar/ Porto center railway station main wall of the Great Valdeves War. [sırlı dekorlu duvar seramiği]. Erişim adresi: http://view.stern.de/de/rubriken/architektur/bahnhofportugal-porto-azulejos-sao-bento-bahnhof-original-3301985.html

Görsel 11. Jorge Colaço. (Mimar). (1868-1942). (Tarihi yap1). Büyük Valdevez Savaşı'nın canlandırıldığı ana duvar renkli üst frizler/ Colourful top friezes of main wall of the Great Valdeves War. [sırlı dekorlu duvar seramiği]. (Kişisel fotoğraf arşivi).

Görsel 12. Jorge Colaço. (Mimar). (1868-1942). (Tarihi yapı). Porto Sao Bento merkez tren istasyonu giriş salonu dini motifler ve taç giyme töreni/ Porto center railway station entrance hall religious motifs and coronation ceramonies. [sırlı dekorlu duvar seramiği]. (Kişisel fotoğraf arşivi). 
Görsel 13. Jorge Colaço. (Mimar). (1868-1942). (Tarihi yap1). Porto Sao Bento merkez tren istasyonu, günlük halk eğlencelerini gösteren betimlemeler/ descriptions of daily public entertainment. [sırlı dekorlu duvar seramiği]. (Kişisel fotoğraf arşivi).

Görsel 14. Jorge Colaço. (Mimar). (1868-1942). (Tarihi yap1). Porto Sao Bento merkez tren istasyonu. Hayvanc1lkla ve rüzgâr değirmenleriyle ilgili betimlemeler/ descriptions of animal farming and wind mills. [sırlı dekorlu duvar seramiği]. (Kişisel fotoğraf arşivi).

Görsel 15. Jorge Colaço. (Mimar). (1868-1942). (Tarihi yapı). Porto Sao Bento merkez tren istasyonu. Denizcilikle ilgili resimli karolar/ ceramic wall panels about maritime. [sırlı dekorlu duvar seramiği]. (Kişisel fotoğraf arşivi).

Görsel 16. Jorge Colaço. (Mimar). (1868-1942). (Tarihi yap1). Porto Sao Bento merkez tren istasyonu. Sembolik tren, saat ve renkli madalyonların işlendiği sırlı yüzey karoları/ ceramic wall panels about clocks and multicolour symbols. [sırlı dekorlu duvar seramiği]. (Kişisel fotoğraf arşivi). 